From the Department of Pathology, College of Veterinary Medicine, Swedish University of Agricultural Sciences, Uppsala, the Department of Pathology, National Veterinary Institute, Uppsala, and the Department of Epidemiology, College of Veterinary Medicine, Swedish University of Agricultural Sciences, Uppsala, Sweden.

\title{
An Outbreak of a Disease in Farmed Fallow Deer (Dama Dama L) Resembling Bovine Virus Diarrhea/Mucosal Disease
}

\author{
By Regina Diaz, Margaretha Steen, Claes Rehbinder and Stefan Alenius
}

\begin{abstract}
Diaz, R., M. Steen, C. Rehbinder and S. Alenius: An outbreak of disease in farmed fallow deer (Dama dama L) resembling Bovine Virus Diarrhea/Mucosal Disease. Acta vet. scand. 1988, 29, 369-376. - Farmed fallow deer suddenly developed disease showing lethargy, weakness, anorexia and several of them died. The animals showed macroscopic lesions in the digestive mucosa characterized by erosions, ulcers and necrotizing lesions. Histo-pathology of the mucous membranes revealed marked inter- and intracellular oedema, erosions, ulcers and intracytoplasmic inclusions bodies. BVD-virus was demonstrated in 1 deer using an indirect immunofluorescence method. It is suggested that the disease may have been caused by Bovine Virus Diarrhea virus alone or in conjunction with a simultaneous infection by another unidentified virus.
\end{abstract}

intracytoplasmic inclusion bodies.

\section{Introduction}

This paper deals with the pathological lesions found in 6 animals brought to the $\mathrm{Na}$ tional veterinary Institute, Uppsala, Sweden, from a farmed fallow deer herd in N. E. Uppland, Sweden. The pathological investigation was supplemented by virological, parasitological and bacteriological investigations of tissue samples obtained at necropsy.

\section{Material and methods}

\section{Animals}

During the early winter 1985 several farmed fallow deer (Dama dama $L$ ) suddenly developed lethargy, weakness, anorexia, and died. The herd was kept in an enclosure erected in 1978, when 2 females and 1 male were in- troduced from a zoo. The herd was supplementary fed. Deaths occurred during late autumn and early winter 1984-1985 when the herd consisted of 21 animals. All 7 calves in the herd died. Several were found dead under the snow. One of these was necropsied and acute infection with Yersinia pseudotuberculosis was diagnosed. More animals, however, continued to die, including adults.

The animals were without any contact with other ruminants except sheep (deer and sheep drank out of the same brook, at both sides of the fence). One animal was observed while showing clinical signs of disease. It was kyphotic, lethargic, dull and with a ruf- 
fled hair coat. The animal died the day after being observed.

The necropsied animals were 4 females and 2 males, aged between 6 months and 4 years. Age was estimated on basis of dental wear and/or the owners statement.

\section{Pathological investigation}

All the animals were submitted for necropsy to the National Veterinary Institute with the history of being found dead.

Mucous membranes were only procured for histology from 4 of the animals showing macroscopic lesions and not being too putrified.

For histological examinations tissues were fixed in $4 \%$ formalin, embedded in paraffin and stained with haematoxylineosin, van Gieson and PAS and according to the Ayoub Shklar method for keratin and prekeratin. From each case, material was taken for routine bacteriological and parasitological examinations.

\section{Virus isolation}

Tissue samples (spleen, lymph nodes and mucous membranes) and blood clots were collected at necropsy. Samples for virus isolation were kept at $-70^{\circ} \mathrm{C}$ until processing. The supernatant of a $10 \%$ suspension of ground tissues or blood clots were analysed for the presence of BVD-virus. The virus isolation was performed by inoculation of $0,1 \mathrm{ml}$ of the samples into 2 roller tube cultures of bovine turbinate (BT) cells. After one passage $0.15 \mathrm{ml}$ of the supernatant was inoculated on cover slip cultures of BT-cells. The cultures were examined for cytopathic effects and 4 days later the cover slips were fixed in acetone and stained by an indirect immunofluorescent method using a hyperimmune serum against BVD-virus produced in swine (Bielefeldt-Ohmann et al. 1981).

\section{Bacteriological and parasitological investigation}

Samples from spleen, lympnodes, liver, lung and intestine were submitted for routine bacteriological examination while material from lung and intestine were submitted for routine parasitological examination.

\section{Results}

\section{Pathological investigation}

The animals were poorly nourished and dehydrated. Macroscopical lesions on the digestive mucosa were found in 4 of the animals. Erosions ulcers and necrotizing lesions were observed in the oral mucosa (tongue, gingiva and palatum molle), and rumen. These lesions were deep, irregularly rounded, 5 to $15 \mathrm{~mm}$ in diameter with elevated margins and red bases (Plate 1). Some of the

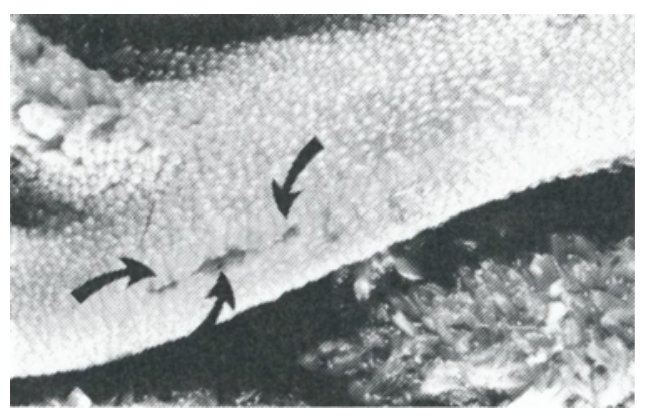

Figure 1. Anterior pillar of the rumen. Note the ulcers (arrows).

animals presented linear erosions in the oesophageal mucosa, covered by a layer of fissured necrotic material (Plate 2). The abomasal mucosa in all the animals was hyperaemic, showing large ulcers in 2 of them.

All the fallow deer had very thin intestinal walls and a watery content in the jejunum. The spleens of 2 animals were thinner and smaller than normal but of normal size in the others. One animal presented very swollen and hyperaemic mesenteric lymph no- 


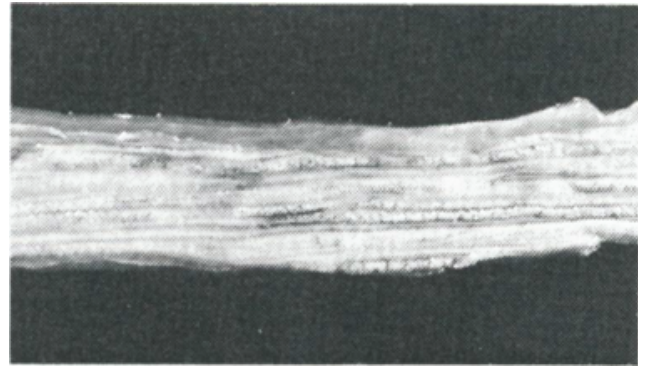

Figure 2. Oesophagus. Note the fissured necrotic material covering linear erosions.

des. The oral-mucous membranes of 2 animals appeared reddened, oedematous but without macroscopic ulcerations or erosions. These animals were, however, not suitable for histological studies due to pronounced postmortem changes.

A foecal pneumonia of the diaphragmatic lobe was observed in one animal. In addition the same animal presented shallow dermal erosions in the interdigital space of the forelimbs. A summary of the macroscopic lesions of the 6 fallow deer is shown in Table 1.
Histologically the mucous membranes of the mouth, oesophageus, and rumen revealed marked inter- and intracellular oedema with some of the cells showing severe vacuolar degeneration. In addition the submucosa was merkedly congested and oedematous. Vesicle-like formations appeared in different mucous membranes as circumscribed areas which were not raised above the adjacent epithelium. The presence of ulcers and erosions was confirmed microscopically. These areas were characterized by loss of epithelium and with the underlaying submucosa covered by bacterial colonies and showing a purulent inflammatory reaction. A mild mononuclear inflammatory infiltrate was present in the lamina propria and submucosa except for the ulcerated areas. Numerous cells of the strata spinosum and granulosum showed changes. They were much bigger than normal, with clear cytoplasm, having nuclei that were either pyknotic or swollen, giving such cells an appearance of a "fried egg". These degenerated cells were often found to form a zone between normal epi-

Table 1. Macroscopic findings.

\begin{tabular}{|c|c|c|c|c|c|c|c|c|}
\hline No. & Mouth & Esophagus & Forestomach & Abomasum & Intestine & Spleen & $\begin{array}{l}\text { Interdigital } \\
\text { space }\end{array}$ & Remarks \\
\hline V 276 & erosion & erosion & erosion & $\begin{array}{l}\text { poor digest } \\
\text { content }\end{array}$ & thin & normal & erosion & $\begin{array}{l}\text { focal pneu- } \\
\text { monia }\end{array}$ \\
\hline V 331 & normal & $\begin{array}{l}\text { erosion } \\
\text { ulcers }\end{array}$ & ulcers & $\begin{array}{l}\text { hemorrhag. } \\
\text { ulcers }\end{array}$ & thin & normal & normal & \\
\hline V 332 & ulcers & normal & ulcers & $\begin{array}{l}\text { erosion } \\
\text { hemorrhag. }\end{array}$ & thin & $\begin{array}{l}\text { thin } \\
\text { small }\end{array}$ & normal & \\
\hline V 436 & normal & normal & $\begin{array}{l}\text { hyperemia } \\
\text { ulcers }\end{array}$ & hyperemia & thin & thin & normal & $\begin{array}{l}\text { positive virus } \\
\text { isolation } \\
\text { BVD-virus }\end{array}$ \\
\hline V 445 & hyperem. & normal & normal & hyperemia & thin & normal & normal & \\
\hline V 446 & hyperem. & normal & $\begin{array}{l}\text { hyperem. } \\
\text { poor digest } \\
\text { content }\end{array}$ & normal & $\begin{array}{l}\text { thin } \\
*\end{array}$ & normal & normal & \\
\hline
\end{tabular}

* Watery content. 
thelial cells below, and degenerated necrotized epithelial cells above.

Numerous cells in the stratum germinativum and spinosum contained intracytoplasmic basophilic inclusion bodies. In general, cells presented 1 inclusion body but in occasional cells 2 could be seen. Inclusion bodies were round, 2 to $10 \mu$ in diameter, and often compressed the nuclei into a crescent shape. The inclusion bodies were surrounded by a clear halo. All the inclusion bodies were negative when stained with Ayob Shklar method for keratin and prekeratin (Fig. 3). The rumen of all animals, presented marked dysplasia and degenerative changes in all the epithelial layers. A common finding was congestion, oedema and depletion of the white pulp of the spleen.

The skin of the interdigital space in 1 animal revealed inter- and intracellular oedema, mild mononuclear infiltration of the dermis and minor erosions of the epithelium. The epithelial changes were similar to the lesions found in the mouth, oesophagus and rumen.

The lungs in all animals showed congestion, slight oedema and slightly increased number of alveolar macrophages. In addition in 2 animals foci of mild subacute alveolar pneu-

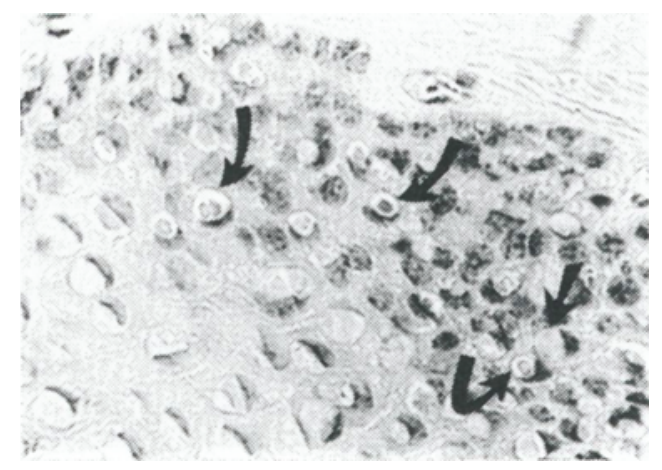

Figure 3. Mucous membrane mouth. Note the swollen cells and the numerous inclusion bodies. $\mathrm{HE} \times 450$. monia were recorded. In 5 animals the liver was congested, oedematous and showed hydropic degeneration of the hepatocytes. In 1 animal hemorrhagic areas and signs of chronic stasis in the centrolobolar veins were observed. The brains showed congestion, oedema, very slight satellitosis and in 1 animal slight mononuclear perivascular cuffing was recorded.

The kidneys appeared without microscopic lesions. Slight degenerative changes were observed in the myocardial fibres in 2 animals.

\section{Virus isolation}

BVD-virus was demonstrated in 1 of the fallow deer. The virus was isolated from the blood clot sample. All other samples were negative. The virus did not produce cytopathic effect (CPE) on the BT cells used and the presence of the BVD-virus was demonstrated using the indirect immunofluorescent method.

\section{Bacteriological and parasitological investigation}

No specific infection by any significant bacteria was recorded. The parasitic burdens of gastrointestinal parasites were found to be none or low.

\section{Discussion}

According to the owner the disease appeared to be of an acute nature while the necropsy findings suggested it to be more of a chronic or subchronic nature. It is hard, however, to define the nutritional status of live deer during winter due to the thick fur.

Several diseases of wild and domestic ruminants are characterized by lesions in the digestive canal. This often makes the diagnosis difficult. In these cases consideration was given to several diseases, e.g. Bovine Virus Diarrhoea/Mucosal Disease (BVD/MD), bovine papular stomatitis, contagious ecthy- 
ma (ORF), malignant catarrhal fever and bluetongue.

Infections with BVD is prevalent among wild ruminants, as indicated by different serological surveys (Romváry 1965, Thorsen \& Henderson 1971, McMartin et al. 1977, Lawman et al. 1978, Couvillon et al. 1980, Elazhary et al. 1981, Weber et al. 1982, Doyl \& Heuschele 1983, Zarnke 1983). Moreover, BVD virus has been isolated from fallow deer in an outbreak of a disease with lesions similar to mucosal disease ( $\mathrm{We}$ ber et al. 1982).

In the present investigation the macroscopic changes were similar to those of BVD/MD but for the lack of changes in the Peyer's patches. The histological lesions were also in many respects similar to those of BVD/MD but for less oedema and less karyorrhexis, and the presence of numerous inclusion bodies.

The inclusion bodies were not similar to those reported by Hansen et al. (1962) from a case of BVD in Sweden, the latter appearing as irregularly shaped intracytoplasmic bodies in some swollen cells of the stratum granulosum of the skin. They stated these inclusion bodies to be of keratin nature.

In our investigation the inclusion bodies were negative to keratin staining and located differently.

Rehbinder et al. (1985) have reported on reindeer (Rangifer tarandus $L$.) showing lesions and inclusion bodies similar to those here described. Those animals were from herds known to be negative for BVD. A possible viral etiology was then suggested but not proved.

Macroscopic and microscopic lesions almost identical to those seen in fallow-deer and reindeer have also been seen i roe-deer ( $\mathrm{Ca}$ preolus capreolus $L$ ) and moose (Alces alces $L$ ). In roedeer and moose BVD has not been considered to be the causative agent (Feinstein et al. 1987).

BVD has an immunosuppressive effect ( $D i$ derholm \& Dinter 1966, Peter et al. 1968, Johnson 1973, Muscoplat et al. 1973, Roth et al. 1981) and could promote the expression of an otherwise asymptomatic or mild disease. Bohac \& Yates (1980) described a case in which it was possible that a calf was chronically infected with BVD which contributed to a severe and prolonged infection by bovine papular stomatitis virus.

Inclusion bodies are a common feature of poxvirus infections (Fenner 1979). Bovine papular stomatitis is a mild disease produced by a parapoxvirus. It is associated with erosions and ulcerations of the digestive mucosa and intracytoplasmic inclusion bodies in the epithelial cells (Griesemer \& Cole $1960,1961)$. The disease could be aggravated by stress and/or other concurrent infectious disease, e.g. BVD (Bohac \& Yates 1980). Histologically, the inclusion bodies as induced by poxvirus are described as both eosinophilic and basophilic (Okada \& Fujimoto 1975). In our investigation only basophilic inclusion bodies have been observed. Contagious ecthyma (ORF) is primarily a disease of domestic sheep and goats caused by a parapoxvirus. It has been diagnosed in several species of wild life from various parts of the world (Smith et al. 1982, Kummeneje 1979, Dietrich et al. 1981, Zarnke 1983, Munz et al. 1986). The lesions of ORF differ macro- and microscopically from the lesions found in our investigation (cauliflower-like papillomatous lesions in skin, eyelids and udder). Microscopically only parts of our findings are similar (balooning of the cells and basophilic inclusion bodies) but there was not acanthosis and/or parakeratosis.

Malignant catarrhal fever is known to occur in deer in North America, Australia, Bri- 
tain, and New Zealand (Senior et al. 1962, Clark et al. 1970, Denholm \& Westbury 1982, Beatson 1985). Among the characteristic features of the disease are erosions and ulcers in large areas of the oral mucosa, hemorrhagic erosions of the abomasum and severe haemorrhagic inflammation of the trachea (Karstad 1970). in addition, widely disseminated vasculitis of small and medium arteries and veins and fibrinoid necrosis of vessel walls are considered pathognomonic lesions. It is known also that in malignant catarrhal fever eosinophilic inclusion bodies do occur. In this investigation some of the macroscopic and microscopic lesions were somewhat similar to those of MCF but the typical vascular lesions were missing.

Bluetongue is an infectious arthropod-borne viral disease producing excoriations of the epithelium of the lips, tongue buccal surfaces, the mucosa of the rumen, reticulum and abomasum. The histopathological lesions consist primarily of oedema, hyperemia, congestion haemorrhages, and intravascular trombosis (Trainer 1970, Beatson 1985). These vascular lesions were not found in our material.

Rinderpest lesions show similarities to those described here, but since Rinderpest is an exotic disease that does not occur in Sweden, it will not be discussed further.

The macroscopical lesions present in the animals in this investigation were similar to lesions found in several diseases. Microscopically, however, the changes were mainly resembling the lesions found in animals affected by Bovine Virus Diarrhea/Mucosal Disease. The main differences are that in BVD/MD in cattle there are more focal areas of oedema, more pyknotic nuclei and no inclusion bodies. A species difference has to be considered, since the tissue response in cervidae may be different to that in cattle. On the other hand reindeer from herds hav- ing no BVD antibodies have showed lesions similar to those found in these fallow-deer (Rehbinder et al. 1985).

It seems possible that several viral diseases may produce similar lesions in the same but also in different species. Bovine virus diarrhea virus was isolated from one of the fallow-deer, and the macro- and microscopical picture corresponded well with that of BVD/MD complex, one of the main differences being the presence of inclusion bodies. It cannot however be excluded that these inclusion bodies are a non-specific cellular response to degenerative cellular changes and thus may be present in different diseases and when other factors are affecting the mucous membranes. If this is relevant, considering the presence of intracytoplasmic inclusion bodies recorded in different species of cervidae (Rehbinder et al. 1985, Feinstein et al. 1987) it seems that the investigated outbreak may have been caused by BVD virus alone or in conjunction with a simultaneous infection by another unidentified virus.

\section{References}

Beatson NS: Field observations of malignant catarrhal fever in red deer in New Zealand. In: Biology of deer production. Proceedings of an International conference held at Dunedin, New Zealand. Royal Society of New Zealand Bulletin 1985, 22, 135-137.

Bielefeldt Ohmann H, Holm Jensen M, Sorensen $K J$, Dalsgaard K: Demonstration of Bovine viral diarrhea virus antigen in cryostat - and paraffin-sections of bovine tissues by the immunoperoxidase technique. Acta path. microbiol. scand. Sect. C. 1981, 89, 281-285.

Bohac JG, Yates WDG: Concurrent bovine virus diarrhea and bovine papular stomatitis infection in a calf. Can. vet. J. 1980, 21, 310-313.

Clark KA, Robinson RM, Marburger RG, Jones $L P$, Orchard JH: Malignant catarrhal fever in Texas cervids. J. Wildl. Dis. 1970, 6, 378383. 
Couvillion CE, Jenney EW, Pearson JE, Coker $M E$ : Survey for antibodies to viruses of bovine virus diarrhea, bluetongue, and epizootic hemorrhagic disease in hunter-killed Mule deer in New Mexico. J. Amer. vet. med. Assoc. 1980, 177, 790-791.

Denholm LJ, Westbury HA: Malignant catarrhal fever in a farmed rusa deer (Cervus timorienusis) 1. Clinico-pathological observations. Aust. vet. J. 1982, 58, 81-87.

Diderholm $H$, Dinter $Z$ : Interference between strains of bovine virus diarrhea virus and their capacity to supress interference of a heterologus virus. Proc. Sve. Expta Biol. Med. 1966, 121, 976-980.

Dieterich RA, Spencer GR, Burger D, Gallina $A M$, Vander $S$ : Contagious ecthyma in alaskan muskoxen and dall sheep. J. Amer. vet. med. Assoc. 1981, 179, 1140-1143.

Doyle LG, Heuschele WP: Bovine viral diarrhea virus infection in captive exotic ruminants. $\mathbf{J}$. Amer. vet. med. Assoc. 1981, 179, 1140-1143. Elazhary MAS, Frechette JL, Silim A, Roy RS: Serological evidence of some bovine viruses in the caribou (Rangifer tarandus caribou) in Quebec. J. Wildl. Dis. 1981, 17(4), 609-612.

Feinstein $R$, Rehbinder C, Rivera E, Nikkilä $T$, Steen M: Intracytoplasmic inclusionbodies associated with vesicular, ulcerative and necrotizing lesions of the digestive mucosa of a roedeer (Capreolus capreolus L) and a moose (Alces alces L). Acta vet. scand. 1987, 28, 197-200.

Fenner F: Portraits of viruses. The poxviruse. Intervirology 1979, 11, 137-157.

Griesemer RA, Cole CR: Bovine papular stomatitis, 1. Recognition in the United States. J. Amer. vet. med. Assoc. 1960, 137, 404-410.

Griesemer RA, Cole CR: Bovine papular stomatitis, 3. Histopathology. Amer. J. vet. Res. 1961, 22, 482-486.

Hansen H-J, Roneus $O$, Dinter Z: Untersuchungen über mucosal disease II. Pathologische anatomie der krankheit im vergleich mit dem cytopathogenen effekt des virus der virusdiarrhöe auf die gewebelkultur. (Investigations on mucosal disease II. A comparison between the pathological picture and the cytopatholo- gical effect on tissueculture). Zbl. Vet. Med. 1962, 9, 854-864.

Johnson DW, Muscoplat CC: Immunological abnormalities in calves with chronic Bovine viral diarrhea. Amer. J. vet. Res. 1973, 34, 1139-1141.

Karstad LH: Malignant catarrhal fever. In: Infectious Diseases of Wild Mammals. Eds: Davis JW, Karstad LH, Träiner DO: Iowa State University Press, Ames, Iowa, USA 1970, p. 134-139.

Kummeneje $K$ : Contagious ecthyma (ORF) in Reindeer (Rangifer Tarandus L). Vet. Rec. 1979, 105, 60-61.

Lawman MJP, Evans D, Gibbs EP, Mc Diarmid $A$, Rowe $L$ : A preliminary survey of British deer for antibody to some virus diseases of farm animals. Brit. vet. J. 1978, 132, 85-91.

Mc Martin DC, Snodgrass DR, Corrigal W: Bovine virus diarrhea antibody in a Scottish red deer. Vet. Rec. 1977, 100, 85-91.

Munz E, Schillinger D, Reimann M, Mahnel H: Electron microscopical diagnosis of ecthyma contagiosum in camels (Cameolus dromedarius). First report of the disease in Kenya. J. Vet. Med. B. 1986, 33, 73-77.

Muscoplat CC, Johnson DW, Stevens JB: Abnormalities of in vitro lymphocytes responses during Bovine viral diarrhea infection. Amer. J. vet. Res. 1973, 34, 753-755.

Okada K, Fujimoto $Y$ : The fine structure of cytoplasmic inclusions and virus particles of bovine papular stomatitis. Jap. J. vet. Res. 1975, 23, 33-40.

Peter CP, Duncan JR, Tyler DE, Romsey FK: Cytopathologic changes of lymphatic tissues of cattle with the bovine virus diarrhea - mu cosal disease complex. Amer. J. vet. Res. 1968, 29, 939-948.

Rehbinder C, Nordkvist M, Moreno JW, Siddiqui I: A suspected virus infection of the oral mucosa in Swedish reindeer (Rangifer tarandus L). Rangifer 1985, 5, 22-31.

Romváry $J$ : Incidence of virus diarrhea among roes. Acta vet. Acad. Sci. Hung. 1965, 15, 451-455.

Roth $J A$, Kaeberle ML, Griffith $R W$ : Effects of bovine viral diarrhea virus infection on bo- 
vine polymorphonuclear leukocyte function. Amer. J. vet. Res. 1981, 42, 244-250.

Senior M, Halnan CR, Tong EH: An outbreak of malignant catarrhal fever among the Pere David deer. Vet. Rec. 1962, 74, 932-936.

Smith TC, Heimer WE, Foreyt WJ: Contagious ecthyma in an adult dall sheep (Ovis dalli dalli) in Alaska. J. Wildl. Dis. 1982, 18, 111 -112 .

Thorsen J, Henderson JP: Survey for antibody to infectious bovine rhinotracheitis (IBR), bovine virus diarrhea (BVD) and parainfluenza 3 (PI3) in moose sera. J. Wild. Dis. 1971, 7, 93-95.

Trainer DO: Bluetongue. In: Infectious Disease of Wild Animals. Eds. Davis, JW, Karstad LH, Trainer DO. Iowa State University Press. Ames, Iowa 1970, p. 55-59.

Weber KH, Hürter KP, Commichau C: Occurrence of viral diarrhea/mucosal disease virus among cervidae in Rheinland/Pfalz. Deutsche Tierärzl. Wochenschr. 1982, 89, 1-3.
Zarnke RL: Serologic survey for selected microbial pathogens in Alaskan wildlife. J. Wildl. Dis. 1983, 19, 324-329.

\section{Sammanfattning}

Ett sjukdomsutbrott bland hägnat dovvilt (Dama dama L) tydande på bovin virus diarre/MD.

Hägnande dovhjortar blev plötsligt sjuka uppvisande, slöhet, svaghet och upphörd foderlust. Ett flertal av dem dog. Djuren uppvisade slemhinneförändringar $\mathrm{i}$ digestionskanalen karakteriserade av erosioner, ulcerationer och nekrotiska förändringar. Histopatologiska undersökningar av slemhinneförändringarna påvisade inter- och intracellulärt ödem, erosioner ulcerationer och intracytoplasmatiska inklusionskroppar. Bovint virusdiarré-virus påvisades hos en hjort med hjälp av indirekt immunofluorescens. Det antas att sjukdomen kan ha orsakats av bovint virus diarre virus ensamt eller tillsammans med ett annat oidentifierat virus.

\section{(Received February 11, 1988).}

Reprints may be requested from: Margaretha Steen, National Veterinary Institute, P. O. Box 7073, S-750 07 Uppsala, Sweden. 